\title{
In vitro antibacterial activity of an aqueous extracts of Matricaria chmomilla flowers against pathogenic bacteria isolated from pregnant women with urinary tract infection.
}

\author{
Ahmed Abduljabbar Jaloob Aljanaby* \\ Department of Biology, Faculty of Science, University of Kufa, Iraq
}

\begin{abstract}
Objective: Matricaria chmomilla is one of the most important medical plants use in both developed and developing countries to treat many infections. The main aim of this study was to investigate the ability of an aqueous extracts of Matricaria chmomilla flowers to inhibit growth of pathogenic bacteria isolated from pregnant women with urinary tract infection.

Methods: This is a descriptive cross-sectional study that was carried out at the laboratory of microbiology in Al-Najaf central hospital in Al-Najaf Governorate, Iraq during March to December 2017. A total of 600 urine samples were collected from 600 pregnant women (age range 25-35 y old) infected with urinary tract infection. Kirby-Bauer method was performed for antibiotic susceptibility testing. Agar well diffusion method was used for the antibacterial activity of cold and boiling water extracts of $M$. chmomilla flowers in three concentrations $(50,100$ and 150$) \mathrm{mg} / \mathrm{ml}$.

Results: Out of 600 urine samples, 654 bacterial strains were isolated. Escherichia coli was the most predominant bacteria (278 isolates, $42.5 \%$ ) followed by Klebsiella pneumoniae (201 isolates, 30.7\%), Acinetobacter baumannii (112 isolates, 17.1\%), Enterobacter aerogenes (23 isolates, 3.5\%), Citrobacter freundii (18 isolates, $2.8 \%$ ), Proteus mirabilis (12 isolates, 1.8\%) and Staphylococcus saprophyticus (10 isolates, $1.6 \%$ ). Imipenem $10 \mu \mathrm{g}$ was the best antimicrobial against all bacterial isolates. Hot water extract $(150 \mathrm{mg} / \mathrm{ml})$ has excellent anti-bacterial activity against all bacterial isolates, the inhibition zone diameters of $E$. coli, $K$. pneumoniae, $A$. baumannii, $E$. aerogenes, $C$. freundii, $P$. mirabilis and $S$. saprophyticus were $29.3 \pm 0.2,26.3 \pm 0.4,26.3 \pm 0.2,28.3 \pm 0.3,29.3 \pm 0.1,29.3 \pm 0.5$ and $28.3 \pm 0.2$, respectively and there was non-significant differences (P-value $>0.05$ ) between imipenem $10 \mu \mathrm{g}$ (positive control) and $150 \mathrm{mg} / \mathrm{ml}$ of hot-water extracts.

Conclusion: Matricaria chmomilla flowers may be considered as a raw material for the manufacture of new drug for treatment of urinary tract infection in human.
\end{abstract}

Keywords: Matricaria chmomilla, Aqueous extracts, Antibacterial, Urinary tract infection.

Accepted on April 30, 2018

\section{Introduction}

Medical plants are one of the most important mean to treat of many bacterial infections due to it has different antibacterial compounds and don't have side effects against human [1]. Matricaria chmomilla (M. chmomilla) also called Matricaria recutita commonly known as German Chamomile or Chamomile belong to family Asteraceae and is widely used as antibacterial in the worldwide such as in Europe, Africa and Asia [2]. Before $1000 \mathrm{y}$ ago, this medical plant was used in Egypt, Greece and Rome to treat different infections and it is considered as one of nine sacred herbs [3,4]. Matricaria chmomilla has been used treat different illness such as gastrointestinal infection, cold and diarrhoea [5,6]. Matricaria chmomilla flowers are one of the most important parts of this plant has been used in many medical treatments like antipyretic and carminative [7]. Urinary Tract Infection (UTI) is one of the most recurrent infections infect individuals especially in women worldwide [8]. Escherichia coli (E. coli), Klebsiella pneumoniae (K. pneumoniae) and other enterobacteriaceae family are the common cause of UTI [9]. The emergence of multi-drug resistant pathogenic bacteria such as $E$. coli, $K$. pneumoniae, Acinetobacter baumannii (A. baumannii) and Staphylococcus saprophyticus ( $S$. saprophyticus) that cause UTI and other different infections led to worsens problem [10-12]. Therefore, these drugs must be replaced with another antibacterial compounds have potent effect against multi-drug resistant pathogens and without side effects against individuals [13]. Urinary tract infection is common in pregnant women [14]. This infection may be cause dangerous complications in fetus during pregnancy; on the other hand, pregnant women infected with UTI cannot intake of antibiotics because of the dangerous effect on the foetus that may be lead to death or distortions after birth. Therefore this study was aimed to 
evaluation of antibacterial effect of hot and cold-water extracts of $M$. chmomilla flowers against pathogenic bacteria isolated from pregnant women with urinary tract infection as alternative medical compounds against these pathogens.

\section{Materials and Methods}

\section{Study design}

This is a descriptive cross-sectional study that was carried out at the Laboratory of Microbiology in Al-Najaf Central Hospital in Al-Najaf Governorate, Iraq during March to December 2017. 600 urine samples were collected from 600 pregnant women (age rang 25-35 y old) infected with urinary tract infection.

\section{Urine culture, identification of bacterial isolates and antibiotics susceptibility test}

All urine samples were streaked immediately onto blood agar (Oxoid, UK) surface and Macconkey agar (Oxoid, UK) surface by sterile loop (Hi-media, India) and incubated aerobically at $37^{\circ} \mathrm{C}$ for $24 \mathrm{~h}$. Any growth of bacterial isolates was in titer $\leq$ $10^{5}$ colony forming units were considered as a positive growth. All bacterial isolates were identified according to standard bacteriological methods [15]. Antibiotics susceptibility testing was performed by a disc diffusion test according to KirbyBauer method [16]. Resistance and sensitive of bacterial isolates to antibiotics were determined according to CLSI guidelines [17].

\section{Collection, identification and preparation of an aqueous extracts of $M$. chmomilla}

Matricaria chmomilla was collected from herbal market of AlNajaf Governorate- Iraq and it was identified by University of Kufa, Faculty of Science, and Department of Botany. Matricaria chmomilla flowers were collected and freed from foreign particles and washed with water to remove dust, dried and ground to powder. $50 \mathrm{~g}$ from flowers were extracted with $500 \mathrm{ml}$ cold sterile water and boiling water for $24 \mathrm{~h}$. The extracted solutions were then filtered through a $0.2 \mu \mathrm{m}$ membrane filter (Whatman, USA) and evaporated at $40^{\circ} \mathrm{C}$ [18]. The extracts were kept in sterile containers (Hi-mediaIndia) at $3^{\circ} \mathrm{C}$ until use.

\section{Antibacterial activity test}

Antibacterial activity testing of cold-water and hot- water extracts was done by use the agar well diffusion method [19] briefly, 5 to 3 fresh bacterial colonies with 0.5 MacFarland turbidity was swabbed onto the Mueller-Hinton agar (Oxoid, UK) agar using sterile swab (Hi-media, India). Three wells with $5 \mathrm{~mm}$ in diameter were made in each Mueller-Hinton agar (Oxoid, UK) surface by sterile cork-borer (Hi-media, India). The crud flowers of $M$. chmomilla extracts were serially diluted to yield dilutions of 50,100 , and $150 \mathrm{mg} / \mathrm{ml} .50 \mu \mathrm{l}$ of each dilution was transfer to each well and left for $3 \mathrm{~h}$ at $20^{\circ} \mathrm{C}$ to enable diffusion of the extract across agar surface and incubated at $37^{\circ} \mathrm{C}$ overnight aerobically. All tests were carried out in triplicates. The inhibition zone around each well was measured in millimetres.

\section{Statistical analysis}

Unpaired T-test was performed in statistical analysis by use SPSS-10 windows software. If $\mathrm{P}$ value $<0.05$ was regarded as indicative of statistical significance. Data were presented in numbers (No) and percentages $(\%)$ and mean \pm standard error of mean.

\section{Results}

Of the 600 urine samples were collected from pregnant women, 654 were positive for bacterial growth. E. coli was the most predominant bacteria $278(42.5 \%)$ followed by $K$. pneumoniae 201 (30.7\%), A. baumannii 112 (17.1\%), E. aerogenes 23 (3.5\%), C. freundii 18 (2.8\%), P. mirabilis 12 $(1.8 \%)$ and S. saprophyticus 10 (1.6\%) (Table 1).

Among 12 antimicrobials were used in susceptibility pattern, all isolates were highly resistant to most antimicrobials, imipenem was the best antimicrobial showed the full activity $(100 \%)$ against most bacterial isolates, therefore it chosen as positive control. The antimicrobials susceptibility pattern of all bacterial isolates is shown in Table 2 and Figure 1.

As shown in Table 3, Hot water extract $(150 \mathrm{mg} / \mathrm{ml})$ has excellent anti-bacterial activity against all bacterial isolates, the inhibition zone diameters of $E$. coli, $K$. pneumoniae, $A$. baumannii, E. aerogenes, $C$. freundii, $P$. mirabilis and $S$. saprophyticus were $29.3 \pm 0.2,26.3 \pm 0.4,26.3 \pm 0.2,28.3 \pm$ $0.3,29.3 \pm 0.1,29.3 \pm 0.5$ and $28.3 \pm 0.2$, respectively and there was non-significant differences (P-value $>0.05$ ) between imipenem $10 \mu \mathrm{g}$ (positive control) and $150 \mathrm{mg} / \mathrm{ml}$ of hot-water extracts as shown in Table 4.

Table 1. Numbers and percentage of pathogenic bacteria isolated from pregnant women with urinary tract infection.

\begin{tabular}{llllllll}
\hline & E. coli & K. pneumoniae & A. baumannii & E. aerogenes & C. freundii & P. mirabilis & S. saprophyticus \\
\hline Single isolate & $256(42.6)$ & $178(29.7)$ & $107(17.8)$ & $19(3.2)$ & $18(3)$ & $12(2)$ & $10(1.7)$ \\
\hline Mix isolates & $22(40.7)$ & $23(42.6)$ & $5(9.3)$ & $4(7.4)$ & $0(0.0)$ & $0(0.0)$ & $0(0.0)$ \\
\hline
\end{tabular}


In vitro antibacterial activity of an aqueous extracts of Matricaria chmomilla flowers against pathogenic bacteria isolated from pregnant women with urinary tract infection

\begin{tabular}{llllllll}
\hline Total & $278(42.5)$ & $201(30.7)$ & $112(17.2)$ & $23(3.5)$ & $18(2.8)$ & $12(1.8)$ & $10(1.5)$
\end{tabular}

Table 2. Resistance pattern of pathogenic bacterial isolates from pregnant women with urinary tract infection.

\begin{tabular}{|c|c|c|c|c|c|c|c|c|}
\hline & $\begin{array}{l}E . \\
\mathbf{( N = 2 7 8 )}\end{array}$ & $\begin{array}{l}K . \quad \text { pneumonia } \\
(\mathbf{N}=\mathbf{1 7 8})\end{array}$ & $\begin{array}{l}\text { A. baumannii } \\
(\mathbf{N}=\mathbf{1 0 7})\end{array}$ & $\begin{array}{l}E . \quad \text { aerogenes } \\
(\mathbf{N}=19)\end{array}$ & $\begin{array}{l}\text { C. freundii } \\
(\mathrm{N}=18)\end{array}$ & $\begin{array}{l}P . \quad \text { mirabilis } \\
\mathbf{( N = 1 2 )}\end{array}$ & $\begin{array}{l}\text { S. saprophyticus } \\
(\mathbf{N}=10)\end{array}$ & Total $(\mathrm{N}=654)$ \\
\hline AMC $30 \mu \mathrm{g}$ & $200(71.9)$ & $170(95.5)$ & $100(93.4)$ & $12(63.1)$ & $14(77.7)$ & $10(83.3)$ & $9(90)$ & $515(78.7)$ \\
\hline CRO $30 \mu \mathrm{g}$ & $195(70.1)$ & $172(96.6)$ & $100(93.4)$ & $12(63.1)$ & $11(61.1)$ & $9(75)$ & $8(80)$ & $507(77.5)$ \\
\hline CTX $30 \mu \mathrm{g}$ & $205(73.7)$ & $170(95.5)$ & 99 (92.5) & 12 (63.1) & $10(55.5)$ & $9(75)$ & $7(70)$ & $512(78.2)$ \\
\hline CAZ $30 \mu \mathrm{g}$ & $185(66.5)$ & 177 (99.4) & 98 (91.5) & $11(57.8)$ & $10(55.5)$ & $9(75)$ & $7(70)$ & $497(75.9)$ \\
\hline $\mathrm{GM} 15 \mu \mathrm{g}$ & $170(61.1)$ & 165 (92.6) & 99 (92.5) & $8(42.1)$ & $8(44.4)$ & $7(58.3)$ & $6(60)$ & $463(70.7)$ \\
\hline TM $10 \mu \mathrm{g}$ & $174(62.5)$ & $160(89.9)$ & $85(79.4)$ & $9(47.3)$ & $8(44.4)$ & $6(50)$ & $5(50)$ & $447(68.3)$ \\
\hline $\mathrm{NA} 30 \mu \mathrm{g}$ & $120(43.1)$ & $155(87)$ & $80(74.7)$ & $9(47.3)$ & $7(38.8)$ & $6(50)$ & $5(50)$ & $382(58.4)$ \\
\hline C $30 \mu \mathrm{g}$ & $166(59.7)$ & $168(94.3)$ & $91(85)$ & $10(52.6)$ & $8(44.4)$ & $8(66.6)$ & $7(70)$ & $458(70)$ \\
\hline CIP $5 \mu \mathrm{g}$ & $167(60)$ & 166 (93.2) & $95(88.7)$ & $9(47.3)$ & $9(50)$ & $7(58.3)$ & $8(80)$ & $461(70.4)$ \\
\hline $\operatorname{LVX} 5 \mu \mathrm{g}$ & $188(67.6)$ & $172(96.6)$ & $100(93.4)$ & $11(57.8)$ & $10(55.5)$ & $10(83.3)$ & $9(90)$ & $500(76.4)$ \\
\hline $\mathrm{F} 30 \mu \mathrm{g}$ & $190(68.3)$ & $161(90.4)$ & $100(93.4)$ & $12(63.1)$ & $12(66.6)$ & $10(83.3)$ & $9(90)$ & $494(75.5)$ \\
\hline IMP $10 \mu \mathrm{g}$ & $0(0.0)$ & $2(1.1)$ & $0(0.0)$ & $0(0.0)$ & $0(0.0)$ & $0(0.0)$ & $0(0.0)$ & $2(0.3)$ \\
\hline
\end{tabular}

Data presented as numbers and percentages of pathogenic bacterial isolates that were resistant to antimicrobials-no (\%); AMC: Amoxicilin with clavulanic acid; CRO: Ceftriaxone; CTX: Cefotaxime; CAZ: Ceftazidime; GM: Gentamicin; TM: Tobramycin; NA: Amikacin; C: Chloramphenicol; CIP: Ciprofloxacin; LVX: Levofloxacin; F: Nitrofurantoin; IMP: Imipenem.

Table 3. Evaluation of the aqueous extracts of Matricaria chmomilla flowers against pathogenic bacteria isolated from pregnant women with urinary tract infection.

\begin{tabular}{|c|c|c|c|}
\hline \multirow[t]{3}{*}{ Pathogenic bacteria } & \multicolumn{3}{|c|}{ Cold-water extracts, $R=3$} \\
\hline & \multicolumn{3}{|c|}{ Concentration, no. (\%), M \pm SE mm } \\
\hline & $50 \mathrm{mg} / \mathrm{ml}$ & $100 \mathrm{mg} / \mathrm{ml}$ & $150 \mathrm{mg} / \mathrm{ml}$ \\
\hline E. coli $(\mathrm{N}=278)$ & $2(0.7)$, Resistance & $10(3.5), 18.3 \pm 0.2$ & 25 (8.9), $18.3 \pm 0.6$ \\
\hline K. pneumoniae $(\mathrm{N}=178)$ & $0(0)$, Resistance & $0(0)$, Resistance & $0(0)$, Resistance \\
\hline A. baumannii $(\mathrm{N}=107)$ & $0(0)$, Resistance & 0 (0), Resistance & 0 (0), Resistance \\
\hline E. aerogenes $(\mathrm{N}=19)$ & 0 (0), Resistance & $1(5.2), 18.3 \pm 0.3$ & $1(5.2), 18.4 \pm 0.2$ \\
\hline C. freundii $(\mathrm{N}=18)$ & $0(0)$, Resistance & $1(5.5), 19.3 \pm 0.1$ & $1(5.5), 19.8 \pm 0.2$ \\
\hline P. mirabilis $(\mathrm{N}=12)$ & $0(0)$, Resistance & $1(8.3), 15.3 \pm 0.5$ & $1(8.3), 19.3 \pm 0.5$ \\
\hline S. saprophyticus $(\mathrm{N}=10)$ & $0(0)$, Resistance & 0 (0), Resistance & 0 (0), Resistance \\
\hline \multirow[t]{3}{*}{ Pathogenic bacteria } & \multicolumn{3}{|c|}{ Hot-water extracts, $R=3$} \\
\hline & \multicolumn{3}{|c|}{ Concentration, no. (\%), M \pm SE mm } \\
\hline & $50 \mathrm{mg} / \mathrm{ml}$ & $100 \mathrm{mg} / \mathrm{ml}$ & $150 \mathrm{mg} / \mathrm{ml}$ \\
\hline E. coli $(\mathrm{N}=278)$ & 87 (31.2), $21.5 \pm 0.2$ & 278 (100), $24.4 \pm 0.2$ & $278(100), 29.3 \pm 0.2$ \\
\hline K. pneumoniae $(\mathrm{N}=178)$ & $66(37), 18.3 \pm 0.2$ & 115 (64.6), $20.3 \pm 0.6$ & 178 (100), $26.3 \pm 0.4$ \\
\hline A. baumannii $(\mathrm{N}=107)$ & $54(50.4), 19.3 \pm 0.7$ & 98 (91.5), $21.3 \pm 0.1$ & $107(100), 26.3 \pm 0.2$ \\
\hline E. aerogenes $(\mathrm{N}=19)$ & 15 (78.9), $20.3 \pm 0.3$ & 19 (100), $20.2 \pm 0.3$ & $19(100), 28.3 \pm 0.3$ \\
\hline
\end{tabular}




\begin{tabular}{llll}
\hline C. freundii $(\mathrm{N}=18)$ & $12(66.6), 20.2 \pm 0.1$ & $18(100), 20.3 \pm 0.1$ & $18(100), 29.3 \pm 0.1$ \\
\hline P. mirabilis $(\mathrm{N}=12)$ & $8(66.6), 21.3 \pm 0.5$ & $12(100), 22.3 \pm 0.5$ & $12(100), 29.3 \pm 0.5$ \\
\hline S. saprophyticus $(\mathrm{N}=10)$ & $7(70), 17.5 \pm 0.2$ & $10(100), 18.3 \pm 0.2$ & $10(100), 28.3 \pm 0.2$ \\
\hline $\begin{array}{l}\text { Data presented as numbers and percentages of pathogenic bacteria that were sensitive to aqueous extracts of Matricaria chmomilla flowers-no (\%); R: Numbers of } \\
\text { replicates; M: Mean of diameter of inhibition zone (mm); SE: Standard Error of mean. }\end{array}$
\end{tabular}

Table 4. Comparison in antibacterial activity between Imipenem $10 \mu \mathrm{g}$ (positive control) and hot-water extract $150 \mathrm{mg} / \mathrm{ml}$ of Matricaria chmomilla flowers against pathogenic bacteria isolated from pregnant women with urinary tract infection.

\begin{tabular}{|c|c|c|c|}
\hline Pathogenic bacteria & $\begin{array}{l}\text { Hot-water } \\
\text { extracts, } \\
150 \mathrm{mg} / \mathrm{ml}, \quad \mathrm{R}=3 \text {, } \\
\text { no. }(\%), M \pm \mathrm{SE} \\
\mathrm{mm} .\end{array}$ & $\begin{array}{l}\text { Imipenem } \quad 10 \quad \mu g, \\
R=3 \text {, no. }(\%), M \pm S E \\
\text { mm. (positive } \\
\text { control) }\end{array}$ & P-value \\
\hline E. coli $(\mathrm{N}=278)$ & $\begin{array}{l}278(100), 29.3 \pm \\
0.2\end{array}$ & $278(100), 28.9 \pm 0.3$ & 0.171 \\
\hline $\begin{array}{l}\text { K. } \\
(\mathrm{N}=178)\end{array}$ & $\begin{array}{l}178(100), 26.3 \pm \\
0.4\end{array}$ & $2(1.1), 27.1 \pm 0.3$ & 0.196 \\
\hline A. baumannii $(\mathrm{N}=107)$ & $\begin{array}{l}107(100), 26.3 \pm \\
0.2\end{array}$ & 107 (100), $26.5 \pm 0.5$ & 0.14 \\
\hline E. aerogenes $(\mathrm{N}=19)$ & $\begin{array}{l}19(100), \quad 28.3 \pm \\
0.3\end{array}$ & 19 (100), $27.9 \pm 0.5$ & 0.573 \\
\hline C. freundii $(\mathrm{N}=18)$ & $\begin{array}{l}18(100), 29.3 \pm \\
0.1\end{array}$ & 18 (100), $30.1 \pm 0.4$ & 0.714 \\
\hline P. mirabilis $(\mathrm{N}=12)$ & $\begin{array}{l}12(100), 29.3 \pm \\
0.5\end{array}$ & 12 (100), $28.8 \pm 0.1$ & 0.236 \\
\hline $\begin{array}{l}\text { S. saprophyticus } \\
(\mathrm{N}=10)\end{array}$ & $\begin{array}{l}10(100), 28.3 \pm \\
0.2\end{array}$ & 10 (100), $27.8 \pm 0.2$ & 0.264 \\
\hline
\end{tabular}

Data presented as numbers and percentages of pathogenic bacterial isolates that were sensitive to Imipenem $10 \mu \mathrm{g}$ and $150 \mathrm{mg} / \mathrm{ml}$ of hot-water extracts of Matricaria chmomilla flowers-no (\%); R: Numbers of replicates; M: Mean of diameter of inhibition zone (mm); SE: Standard Error of mean.

\section{Discussion}

Matricaria chmomilla is one of the best medical plants were used to treat different infections before $1000 \mathrm{y}$ ago in different countries [20]. According to the best of our knowledge, this is the first study in Iraq aimed to evaluate the antibacterial activity of cold-water and boiling-water extracts of Matricaria chmomilla flowers against pathogenic bacteria isolated from pregnant women with UTI. In this study, E. coli was the most common bacteria isolated from urine of pregnant women with UTI followed by $K$. pneumoniae and A. baumannii as shown in Table 1. Gram-negative bacteria belong to enterobacteriaceae family is one of the most etiological agents of UTI with percentage in-between $80 \%$ to $90 \%$ [21,22]. While, grampositive bacteria comes in the second degree, for example, $S$. saprophyticus is the second most common cause UTI in females with percentage between $30 \%$ to $40 \%$ [23]. Most gram-negative bacteria as well as some of gram-positive bacteria have different virulence factors such as fimbriae, biofilms and capsule that enabling these pathogens to attachment, persistence and colonization in the bladder epithelium of urinary tract and cause infection [24,25]. Our findings showed that most bacterial isolates were resistant to most antibiotics with high percentages as shown in Table 2 and Figure 1, these results are similar with many previous studies in different countries such as, in Egypt, Uganda, India and Nigeria [26-29]. Overuse of different classes of antibiotics such as; aminoglycosides, beta-lactams, 3rd and 4th generation cephalosporin's and quinolones to treat this infection, lead to emerging of new highly antibiotics resistant bacterial strains due to vertical and horizontal transfer of antibiotics resistant gene between different bacterial isolates in the same family or to different family [30-33]. Therefore, many medical plants were used to treat different infections as an alternative medical compounds against highly drug resistant pathogens because of it is contain rich source of traditional medicines $[1,18]$. In this study, we aimed to evaluate the antibacterial effect of three concentrations (50, 100 and 150) $\mathrm{mg} / \mathrm{ml}$ of cold-water and boiling-water extracts of $M$. chmomilla flowers to inhibit growth of pathogenic bacteria isolated from urine of pregnant women with UTI, the results showed that $150 \mathrm{mg} / \mathrm{ml}$ of boilingwater extract had excellent effect against all bacterial isolates with inhibition percentage $100 \%$, the inhibition zone diameters of E. coli, K. pneumoniae, A. baumannii, E. aerogenes, $C$. freundii, $P$. mirabilis and $S$. saprophyticus were $29.3 \pm 0.2$, $26.3 \pm 0.4,26.3 \pm 0.2,28.3 \pm 0.3,29.3 \pm 0.1,29.3 \pm 0.5$ and $28.3 \pm 0.2$, respectively .while other concentrations of coldwater and boiling-water extracts don't provided full antibacterial activity against all bacterial isolates as shown in Table 3, and there was non-significant differences (Pvalue $>0.05)$ in antibacterial effect between imipenem $10 \mu \mathrm{g}$ (positive control) and $150 \mathrm{mg} / \mathrm{ml}$ of hot-water extracts (Table 4). Matricaria chamomilla is an important medicinal plant was used in treatment of many infections such as respiratory tract infections and gastrointestinal tract infections in many countries [34]. Matricaria chamomilla flowers was used as antipyretic and carminative, in addition, flowers oil has been used in colic, flatulence and rheumatism [35]. One of the most abundant components of the essential flowers oil, apart from it is spasmolytic effects on intestinal smooth muscle [36,37]. Also, has been reported to have antibacterial, antipyretic, antifungal and anti-inflammatory as well as ulcer protective effect [38-40]. Matricaria chamomilla which have been associated with relieved hypertensive symptoms and decreases the systolic blood pressure, increasing urinary output and may be lead to decrease the numbers of pathogenic bacteria in urinary tract [41]. Also, drinking M. chamomilla was associated with increase in urinary levels of hippurate and glucine, which have been associated with increased antibacterial activity [42]. In the present study, boiling-water 
extract had a significant antibacterial activity as compare with cold-water extract; this may be due to that the boiling water has the ability to extracted more medical compounds from flowers more than cold water.

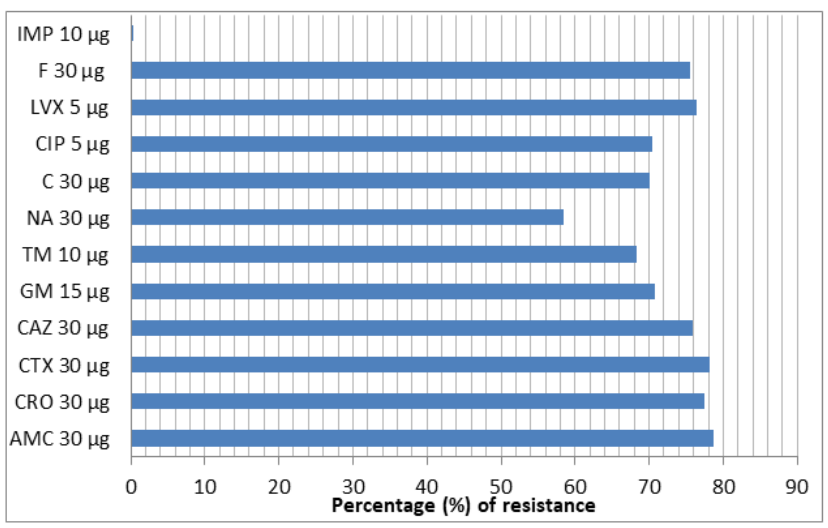

Figure 1. Overall resistance to 12 antimicrobials of 654 bacterial isolates from pregnant women with urinary tract infection. AMC: Amoxicilin with clavulanic acid; CRO: Ceftriaxone; CTX: Cefotaxime; CAZ: Ceftazidime; GM: Gentamicin; TM: Tobramycin; NA: Amikacin; C: Chloramphenicol; CIP: Ciprofloxacin; LVX: Levofloxacin; F: Nitrofurantoin; IMP: Imipenem.

\section{Conclusion}

This study showed that boiling-water extract $(150 \mathrm{mg} / \mathrm{ml})$ of M. chmomilla flowers extract has excellent antibacterial activity against all bacterial isolates from pregnant women with UTI. So, M. chmomilla flowers may be considered as a raw material for the manufacture of new drug for treatment of urinary tract infection.

\section{References}

1. Aljanaby AAJ. Antibacterial activity of an aqueous extracts of Alkanna tinctoria roots against drug resistant aerobic pathogenic bacteria isolated from patients with burns infections. ROMJ 2018; 1: 1-6.

2. Mehmood MH, Munir S, Khalid UA, Asrar M, Gilani AH. Antidiarrhoeal, antisecretory and antispasmodic activities of Matricaria chamomilla are mediated predominantly through $\mathrm{K}(+)$-channels activation. BMC Complement Altern Med 2015; 15: 75.

3. Issac $O$. Recent progress in chamomile researchmedicines of plant origin in modern therapy (1st ed). Prague Press 1989.

4. Crevin JK, Philpott J. Herbal medicine past and present (1st ed). Duke Univ Press, USA 1990.

5. Singh O, Khanam Z, Misra N, Srivastava MK. Chamomile (Matricaria chamomilla L.): an overview. Pharmacogn Rev 2011; 5: 82-95.

6. Romha G, Admasu B, Hiwot Gebrekidan T, Aleme H, Gebru G. Antibacterial activities of five medicinal plants in ethiopia against some human and animal pathogens. Evid Based Complement Alternat Med 2018; 2018: 2950758.
7. Baquar SR. Matricaria chamomilla L. In: Medicinal and poisonous plants of Pakistan. Printas Karachi, Karachi, Pakistan 1989; 278.

8. Mody L, Juthani-Mehta M. Urinary tract infections in older women: a clinical review. JAMA 2014; 311: 844-854.

9. Aljanaby AAJ, Alhasnawi HMRJ. Phenotypic and molecular characterization of multidrug resistant Klebsiella pneumoniae isolated from different clinical sources in Al-Najaf Province-Iraq. Pak J Biol Sci 2017; 20: 217-232.

10. Aljanaby AAJ, Aljanaby IAJ. Profile of antimicrobial resistance of aerobic pathogenic bacteria isolated from different clinical infections in Al-Kufa Central HospitalIraq During period from 2015 to 2017. Res J Pharm Tech 2017; 10: 3264-3270.

11. Ma JG, An JX. Deep sternal wound infection after cardiac surgery: a comparison of three different wound infection types and an analysis of antibiotic resistance. J Thorac Dis 2018; 10: 377-387.

12. Asaad AM, Ansar Qureshi M, Mujeeb Hasan S. Clinical significance of coagulase-negative staphylococci isolates from nosocomial bloodstream infections. Infect Dis (Lond) 2016; 48: 356-360.

13. Schilcher $\mathrm{H}$, Imming $\mathrm{P}$, Goeters $\mathrm{S}$. Active chemical constituents of Matricaria chamomilla L. syn. Chamomilla recutita L. Chamomile-industrial profiles. CRC Press 2005; 55-76.

14. Ghouri F, Hollywood A, Ryan K. A systematic review of non-antibiotic measures for the prevention of urinary tract infections in pregnancy. BMC Pregnancy Childbirth 2018; 18: 99.

15. MacFaddin JF. Biochemical Tests for identification of medical bacteria (3rd ed). Williams and Wilkins, Philadelphia 2000; 912.

16. Bauer AW, Kirby WM, Sherris JC, Turck M. Antibiotic susceptibility testing by standard single disc method. Am J Clin Pathol 1966; 45: 493-496.

17. Franklin RC. Performance standards for antimicrobial susceptibility testing; twenty-third informational supplement. Clin Laboratory Standards Institute USA 2017.

18. Aljanaby AAJJ. Antibacterial activity of an aqueous extract of Petroselinum crispum leaves against pathogenic bacteria isolated from patients with burns infections in AlNajaf Governorate, Iraq. Res Chem Intermed 2013; 39: 3709.

19. Radji M, Agustama RA, Elya B, Tjampakasari CR. Antimicrobial activity of green tea extract against isolates of methicillin resistant Staphylococcus aureus and multidrug resistant Pseudomonas Aeruginosa. Asian Pac J Trop Biomed 2013; 3: 663-667.

20. Grieve M, Leyel CF. The medicinal, culinary, cosmetic and economic properties, cultivation and folklore of herbs, grasses, fungi, shrubs and trees with all their modern scientific uses. In: A modern herbal. Tiger books 
International, Mackays of Chatham, PLC, Chatham, Kent 1994; 961-962.

21. Kumar MS, Das AP. Molecular identification of multi drug resistant bacteria from urinary tract infected urine samples. Microb Pathog 2016; 98: 37-44.

22. Shalekenov BU, Bissekenova AL, Ramazanova BA, Adambekov DA, Shalekenov SB. Species composition and molecular-genetic characteristics of antibioticresistant strains of gram negative bacteria isolated from patients of a hospitals urology department. Urologiia 2018; 1: 77-83.

23. Pailhoriès $H$, Cassisa V, Chenouard R, Kempf M, Eveillard M, Lemarié C. Staphylococcus saprophyticus: Which beta-lactam? Int J Infect Dis 2017; 65: 63-66.

24. Kalas V, Hibbing ME, Maddirala AR, Chugani R, Pinkner JS, Mydock-McGrane LK, Conover MS, Janetka JW, Hultgren SJ. Structure-based discovery of glycomimetic FmlH ligands as inhibitors of bacterial adhesion during urinary tract infection. Proc Natl Acad Sci U S A 2018; 115: 2819-2828.

25. Anderson GG, Palermo JJ, Schilling JD, Roth R, Heuser J, Hultgren SJ. Intracellular bacterial biofilm-like pods in urinary tract infections. Science 2003; 301: 105-107.

26. Abdel-Aziz Elzayat M, Barnett-Vanes A, Dabour MF, Cheng F. Prevalence of undiagnosed asymptomatic bacteriuria and associated risk factors during pregnancy: a cross-sectional study at two tertiary centres in Cairo, Egypt. BMJ Open 2017; 7: e013198.

27. Sekikubo M, Hedman K, Mirembe F, Brauner A. Antibiotic overconsumption in pregnant women with urinary tract symptoms in Uganda. Clin Infect Dis 2017; 65: 544-550.

28. Sibi G, Kumari P, Kabungulundabungi N. Antibiotic sensitivity pattern from pregnant women with urinary tract infection in Bangalore, India. Asian Pac J Trop Med 2014; 7S1: 116-120.

29. Onoh R, Umeora O, Egwuatu V, Ezeonu P, Onoh T. Antibiotic sensitivity pattern of uropathogens from pregnant women with urinary tract infection in Abakaliki, Nigeria. Infect Drug Resist 2013; 6: 225-233.

30. Aljanaby AA, Gafil FA. Effect of different antibiotics on aerobic pathogenic bacteria and urinary tract infection in Al-Manathera City, Iraq: a comparative study. Res Chem Intermed 2013; 39: 3679-3687.

31. Khosravi AD, Hoveizavi H, Mohammadian A, Farahani A, Jenabi A. Genotyping of multidrug-resistant strains of Pseudomonas aeruginosa isolated from burn and wound infections by ERIC-PCR. Acta Cir Bras 2016; 31: 206-211.

32. Parhizgari N, Khoramrooz SS, Malek Hosseini SA, Marashifard M, Yazdanpanah M, Emaneini M. High frequency of multidrug-resistant Staphylococcus aureus with SCCmec type III and Spa types t037 and t631 isolated from burn patients in southwest of Iran. APMIS 2016; 124: 221-228.

33. Aljanaby AAJ, Medhat AR. Prevalence of some antimicrobials resistance associated-genes in Salmonella typhi Isolated from patients infected with typhoid fever. J Biol Sci 2017; 17: 171-184.

34. Awaad AA, El-Meligy RM, Zain GM, Safhi AA, A Qurain NA, Almoqren SS, Zain YM, Sesh Adri VD, AlSaikhan FI. Experimental and clinical antihypertensive activity of Matricaria chamomilla extracts and their angiotensin-converting enzyme inhibitory activity. Phytother Res 2018.

35. Baquar SR. Matricaria chamomilla L. In: Medicinal and poisonous plants of Pakistan. Karachi, Pakistan: Printas Karachi 1989. p. 278.

36. Achterrath-Tuckermann U, Kunde R, Flaskamp E, Isaac $\mathrm{O}$, Thiemer $\mathrm{K}$. Pharmacological investigations with compounds of chamomile. V. Investigations on the spasmolytic effect of compounds of chamomile and Kamillosan on the isolated guinea pig ileum. Planta Medica 1980; 39: 38-50.

37. Forster H B, Niklas H, Lutz S. Antispasmodic effects of some medicinal plants. Planta Medica 1980; 40: 309-319.

38. Berry M. Herbal products (Part 6). Chamomiles. Pharmacol J 1995; 254: 191-193.

39. Blumenthal M. The complete German commission and monographs. Therapeutic guide to herbal medicines. Integr Med Communications, Austin, Texas 2000.

40. Isaac O, Thiemer K. Pharmacological investigations with compounds of chamomile. V. Investigations on the spasmolytic effect of compounds of chamomile and Kamillosan on the isolated guinea pig ileum. Planta Medica 31980; 9: 38-50.

41. Zeggwagh NA, Moufid A, Michel JB, Eddouks M. Hypotensive effect of Chamaemelum nobile aqueous extract in spontaneously hypertensive rats. Clin Exp Hypertens 2009; 31: 440-450.

42. Wang Y, Tang H, Nicholson JK, Hylands PJ, Sampson J, Holmes E. A metabonomic strategy for the detection of the metabolic effects of chamomile (Matricaria recutita L.) ingestion. J Agric Food Chem 2005; 53: 191-196.

\section{*Correspondence to}

Ahmed Abduljabbar Jaloob Aljanaby

Department of Biology

Faculty of Science

University of Kufa

Iraq 